\title{
Antifungal agents for the treatment of systemic fungal infections in children
}

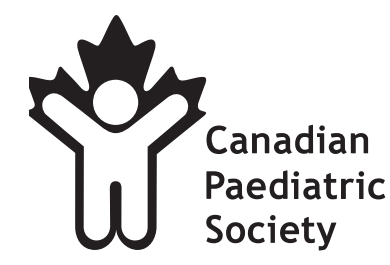

\author{
UD Allen; Canadian Paediatric Society, Infectious Diseases and Immunization \\ Committee
}

UD Allen; Canadian Paediatric Society, Infectious Diseases and Immunization Committee. Antifungal agents for the treatment of systemic fungal infections in children. Can J Infect Dis Med Microbiol 2010;21(4):e116-e121.

Traditionally, the mainstay of systemic antifungal therapy has been amphotericin B deoxycholate (conventional amphotericin B). Newer agents have been developed to fulfill special niches and to compete with conventional amphotericin B by virtue of having more favourable toxicity profiles. Some agents have displaced conventional amphotericin B for the treatment of specific fungal diseases. For example, voriconazole has emerged as the preferred treatment for invasive pulmonary aspergillosis. This notwithstanding, conventional amphotericin B remains a useful agent for the treatment of paediatric fungal infections. Knowledge of the characteristics of the newer agents is important, given the increasing numbers of patients who are being treated with these drugs. Efforts need to be directed at research aimed at generating paediatric data where these are lacking. The antifungal agents herein described are most often used as monotherapy regimens because there is no uniform consensus on the value of combination therapy, except for specific scenarios.

Key Words: Amphotericin B; Antifungal therapy; Echinocandins; Triazoles
UD Allen; Société canadienne de pédiatrie, comité des maladies infectieuses et d'immunisation. Les antifongiques pour le traitement des infections fongiques systémiques chez les enfants

\begin{abstract}
Le désoxycholate d'amphotéricine B (amphotéricine B classique) a toujours été la principale thérapie antifongique systémique. Les agents plus récents ont été mis au point pour occuper des créneaux spéciaux et pour faire concurrence à l'amphotéricine B classique grâce à des profils de toxicité plus favorables. Certains agents ont fait reculer l'amphotéricine B classique pour traiter des maladies fongiques précises. Par exemple, le voriconazole émerge comme traitement de choix contre l'aspergillose pulmonaire envahissante. Malgré tout, l'amphotéricine B classique demeure un agent utile pour traiter les infections fongiques en pédiatrie. Il faut connaître les caractéristiques des nouveaux agents étant donné le nombre croissant de patients traités à l'aide de ces médicaments. Il faut également orienter les efforts vers des recherches visant à obtenir des données pédiatriques dans les secteurs où on n'en possède pas. Les antifongiques décrits dans le présent commentaire sont surtout utilisés en monothérapie, parce qu'il n'existe pas de consensus uniforme sur la valeur d'une polythérapie, sauf dans des scénarios précis.
\end{abstract}

$\mathrm{O}$ ver the past 15 years, there has been a major increase in the number of available antifungal agents. The newer agents have been evaluated to a lesser degree in children compared with adults (1). The present overview offers a perspective on amphotericin B deoxycholate and the newer antifungal agents, as well as their roles in paediatric antifungal therapy.

\section{AMPHOTERICIN B PRODUCTS}

Preparations, dosing and toxicity profiles

Amphotericin B products are available as parenteral agents. Newer and more costly (lipid-based) formulations of amphotericin $\mathrm{B}$ are increasingly being used in clinical practice (2-7). The major toxicities associated with amphotericin B are nephrotoxicity and infusion-related events (fevers, chills and rigors) (8). The lipid-based products are less nephrotoxic, with comparable efficacy relative to conventional amphotericin B (amphotericin B deoxycholate). The dosing of these agents, indications and body fluid concentrations are shown in Table 1.
Clinical use in paediatrics: Amphotericin B is a broadspectrum antifungal agent (Table 2). The variable agents (amphotericin B products) have comparable efficacy, although in some clinical settings, the lipid products might be advantageous because higher doses per unit body weight can be used while preserving renal function. The lipidbased products are usually recommended in patients who are refractory to or intolerant of amphotericin B deoxycholate (9). The lipid-based agents that are most readily available for clinical use are amphotericin B lipid complex and liposomal amphotericin B. A third lipid-based product, amphotericin B colloidal dispersion, is associated with more fever and chills compared with conventional amphotericin (10).

\section{THE TRIAZOLES}

Preparations, dosing and toxicity profiles

Fluconazole: Fluconazole is an oral and parenteral agent. It readily penetrates into tissues due to its low lipophilic nature and limited protein binding; it is approximately $90 \%$ 
TABLE 1

Antifungal agents for the treatment of systemic fungal infections in children

\begin{tabular}{|c|c|c|c|c|c|c|}
\hline \multirow[b]{2}{*}{ Agent } & \multirow{2}{*}{$\begin{array}{l}\text { Routes of } \\
\text { administration/ } \\
\text { relative costs* }\end{array}$} & \multirow[b]{2}{*}{ Dosage/day } & \multirow[b]{2}{*}{$\begin{array}{l}\text { Most common } \\
\text { indications for use }^{\dagger}\end{array}$} & \multirow[b]{2}{*}{$\begin{array}{l}\text { Adverse events/ } \\
\text { cautionary notes }\end{array}$} & \multicolumn{2}{|c|}{ Body fluid concentrations ${ }^{\ddagger}$} \\
\hline & & & & & $\begin{array}{l}\text { CSFIserum/ } \\
\text { comments }\end{array}$ & Other sites \\
\hline $\begin{array}{l}\text { Amphotericin B } \\
\text { deoxycholate }\end{array}$ & $\begin{array}{l}\text { IV: \$ } \\
\quad \text { (for } 1 \mathrm{mg} / \mathrm{kg} / \text { day) }\end{array}$ & $\begin{array}{l}0.25 \mathrm{mg} / \mathrm{kg} \text { to } 0.5 \mathrm{mg} / \mathrm{kg} \\
\text { initially, increased to } \\
0.5 \mathrm{mg} / \mathrm{kg} \text { to } 1.5 \mathrm{mg} / \mathrm{kg}^{\S} \\
\text { Dosage for aspergillosis: } \\
1.5 \mathrm{mg} / \mathrm{kg}\end{array}$ & $\begin{array}{l}\text { Invasive fungal infections } \\
\text { caused by susceptible } \\
\text { organisms as shown in } \\
\text { Table } 2 \\
\text { Empirical therapy of } \\
\text { presumed fungal } \\
\text { infections in febrile } \\
\text { neutropenic patients }\end{array}$ & $\begin{array}{l}\text { Infusion-related toxicity } \\
\text { Nephrotoxicity, including } \\
\text { hypokalemia } \\
\text { Medication errors have } \\
\text { occurred due to confusion } \\
\text { between the lipid-based } \\
\text { products and } \\
\text { conventional } \\
\text { amphotericin B. The dose } \\
\text { of conventional } \\
\text { amphotericin B should } \\
\text { not exceed } 1.5 \mathrm{mg} / \mathrm{kg} / \mathrm{day}\end{array}$ & (1) & $\begin{array}{l}\text { Newborn serum/ } \\
\text { maternal serum = } \\
50 \% \\
\text { Aqueous humor/ } \\
\text { serum }=25 \%\end{array}$ \\
\hline $\begin{array}{l}\text { Liposomal } \\
\text { amphotericin B } \\
\text { (AmBisome) }\end{array}$ & $\begin{array}{l}\text { IV: } \$ \$ \$ \\
\text { (for } 3 \mathrm{mg} / \mathrm{kg} / \text { day) }\end{array}$ & $\begin{array}{l}3 \mathrm{mg} / \mathrm{kg} \text { to } 5 \mathrm{mg} / \mathrm{kg} \\
\text { Dosage for aspergillosis: } \\
\text { AmBisome } 5 \mathrm{mg} / \mathrm{kg} \text { to } \\
10 \mathrm{mg} / \mathrm{kg} \text {; likely up to } \\
10 \mathrm{mg} / \mathrm{kg}\end{array}$ & $\begin{array}{l}\text { Invasive fungal } \\
\text { infections, refractory or } \\
\text { intolerance to } \\
\text { conventional } \\
\text { amphotericin B }\end{array}$ & $\begin{array}{l}\text { Fewer infusion-related } \\
\text { reactions and } \\
\text { nephrotoxicity than } \\
\text { amphotericin B } \\
\text { deoxycholate }\end{array}$ & $\begin{array}{l}\text { Higher levels } \\
\text { may be } \\
\text { achievable in } \\
\text { brain tissue } \\
\text { due to } \\
\text { potential for } \\
\text { greater per kg } \\
\text { dosing }\end{array}$ & $\begin{array}{l}\text { Concentrates in } \\
\text { reticulo-endothelial } \\
\text { system }\end{array}$ \\
\hline $\begin{array}{l}\text { Amphotericin B } \\
\text { lipid complex } \\
\text { (Abelcet) }\end{array}$ & $\begin{array}{l}\text { IV: } \$ \$ \$ \$ \\
\text { (for } 5 \mathrm{mg} / \mathrm{kg} / \text { day) }\end{array}$ & $\begin{array}{l}5 \mathrm{mg} / \mathrm{kg} \\
\text { Dosage for aspergillosis: } \\
\text { Abelcet } 5 \mathrm{mg} / \mathrm{kg} \text { to } \\
10 \mathrm{mg} / \mathrm{kg} \text {; likely up to } \\
7.5 \mathrm{mg} / \mathrm{kg}\end{array}$ & $\begin{array}{l}\text { Invasive fungal } \\
\text { infections; refractory or } \\
\text { with intolerance to } \\
\text { conventional } \\
\text { amphotericin B }\end{array}$ & $\begin{array}{l}\text { Less nephrotoxicity than } \\
\text { amphotericin B } \\
\text { deoxycholate }\end{array}$ & $\begin{array}{l}\text { Higher levels } \\
\text { may be } \\
\text { achievable in } \\
\text { brain tissue } \\
\text { due to poten- } \\
\text { tial for greater } \\
\text { per kg dosing }\end{array}$ & $\begin{array}{l}\text { Concentrates in } \\
\text { reticulo-endothelial } \\
\text { system }\end{array}$ \\
\hline Fluconazole & $\begin{array}{l}\text { PO; IV } \\
\text { PO: } \$ \\
\text { (for } 5 \mathrm{mg} / \mathrm{kg} / \text { day) } \\
\text { IV: } \$ \\
\text { (for } 5 \mathrm{mg} / \mathrm{kg} / \text { day) }\end{array}$ & $\begin{array}{l}\text { PO: } 6 \mathrm{mg} / \mathrm{kg} \text { once, then } \\
3 \mathrm{mg} / \mathrm{kg} / \text { day for } \\
\text { oropharyngeal or } \\
\text { esophageal candidiasis; } \\
6 \mathrm{mg} / \mathrm{kg} / \text { day to } \\
12 \mathrm{mg} / \mathrm{kg} / \text { day for invasive } \\
\text { fungal infections; } \\
6 \mathrm{mg} / \mathrm{kg} / \text { day for } \\
\text { suppressive therapy in } \\
\text { HIV-infected children with } \\
\text { cryptococcal meningitis } \\
\text { IV: } 3 \mathrm{mg} / \mathrm{kg} \text { to } 6 \text { mg/kg, } \\
\text { single dose; up to } \\
12 \text { mg/kg per day for } \\
\text { serious infections }\end{array}$ & $\begin{array}{l}\text { Candida infections } \\
\text { (eg, intra-abdominal } \\
\text { abscess, peritonitis, } \\
\text { pleural space } \\
\text { infection, candidemia, } \\
\text { esophageal candidiasis, } \\
\text { oropharyngeal } \\
\text { candidiasis, Candida } \\
\text { urinary tract infections, } \\
\text { endophthalmitis) } \\
\text { Cryptococcal infections } \\
\text { Antifungal prophylaxis in } \\
\text { HSCT patients and } \\
\text { neonates }\end{array}$ & $\begin{array}{l}\text { Rare, serious } \\
\text { hepatotoxicity possible } \\
\text { Cytochrome P450 } \\
\text { isoenzyme drug } \\
\text { interactions }\end{array}$ & $50 \%$ to $94 \%$ & $\begin{array}{l}\text { Newborn serum/ } \\
\text { maternal serum = } \\
85 \%\end{array}$ \\
\hline Itraconazole & $\begin{array}{l}\text { PO; IV } \\
\text { PO: } \$ \\
\quad \text { (for } 5 \text { mg/kg/day) } \\
\text { IV: (Not marketed) }\end{array}$ & $\begin{array}{l}\text { IV, PO: } 5 \mathrm{mg} / \mathrm{kg} / \text { day to } \\
10 \mathrm{mg} / \mathrm{kg} / \text { day divided into } \\
2 \text { doses }\end{array}$ & $\begin{array}{l}\text { Invasive and noninvasive } \\
\text { aspergillosis, } \\
\text { oropharyngeal and } \\
\text { esophageal candidiasis } \\
\text { Blastomycosis } \\
\text { Chronic pulmonary } \\
\text { histoplamosis } \\
\text { Antifungal prophylaxis in } \\
\text { HSCT and lung } \\
\text { transplant patients }\end{array}$ & $\begin{array}{l}\text { Elevated liver enzymes } \\
\text { Gastrointestinal } \\
\text { intolerance: abdominal } \\
\text { pain, vomiting, } \\
\text { diarrhea } \\
\text { Cytochrome P450 } \\
\text { isoenzyme drug } \\
\text { interactions }\end{array}$ & $<10 \%$ & $\begin{array}{l}\text { Tissue and bronchial } \\
\text { secretions levels } \\
\text { higher than plasma } \\
\text { Ocular levels low }\end{array}$ \\
\hline Voriconazole & $\begin{array}{l}\text { PO; IV } \\
\text { PO: } \$ \$ \\
\text { (for } 100 \mathrm{mg} \text { PO bid) } \\
\text { IV: } \$ \$ \$ \\
\quad \text { (for } 8 \mathrm{mg} / \mathrm{kg} / \text { day) }\end{array}$ & $\begin{array}{l}\text { PO: } 8 \mathrm{mg} / \mathrm{kg} \text { every } 12 \mathrm{~h} \text { for } \\
\text { one day, then } 7 \mathrm{mg} / \mathrm{kg} \\
\text { every } 12 \mathrm{~h} \\
\mathrm{IV}: 6 \mathrm{mg} / \mathrm{kg} \text { to } 8 \mathrm{mg} / \mathrm{kg} \\
\text { every } 12 \mathrm{~h} \text { for one day, } \\
\text { then } 7 \mathrm{mg} / \mathrm{kg} \text { every } 12 \mathrm{~h}\end{array}$ & $\begin{array}{l}\text { Invasive aspergillosis } \\
\text { Esophageal candidiasis } \\
\text { Refractory infections due } \\
\text { to Scedosporium, } \\
\text { Angiospermum and } \\
\text { Fusarium species }\end{array}$ & $\begin{array}{l}\text { Main side effects are } \\
\text { liver function } \\
\text { abnormalities, skin rash, } \\
\text { visual disturbances, } \\
\text { CYP450 isoenzyme drug } \\
\text { interactions }\end{array}$ & $42 \%$ to $67 \%$ & $\begin{array}{l}\text { Excellent tissue } \\
\text { penetration; levels } \\
\text { exceed trough } \\
\text { plasma levels } \\
\text { several fold }\end{array}$ \\
\hline
\end{tabular}


TABLE 1 - CONTINUED

Antifungal agents for the treatment of systemic fungal infections in children

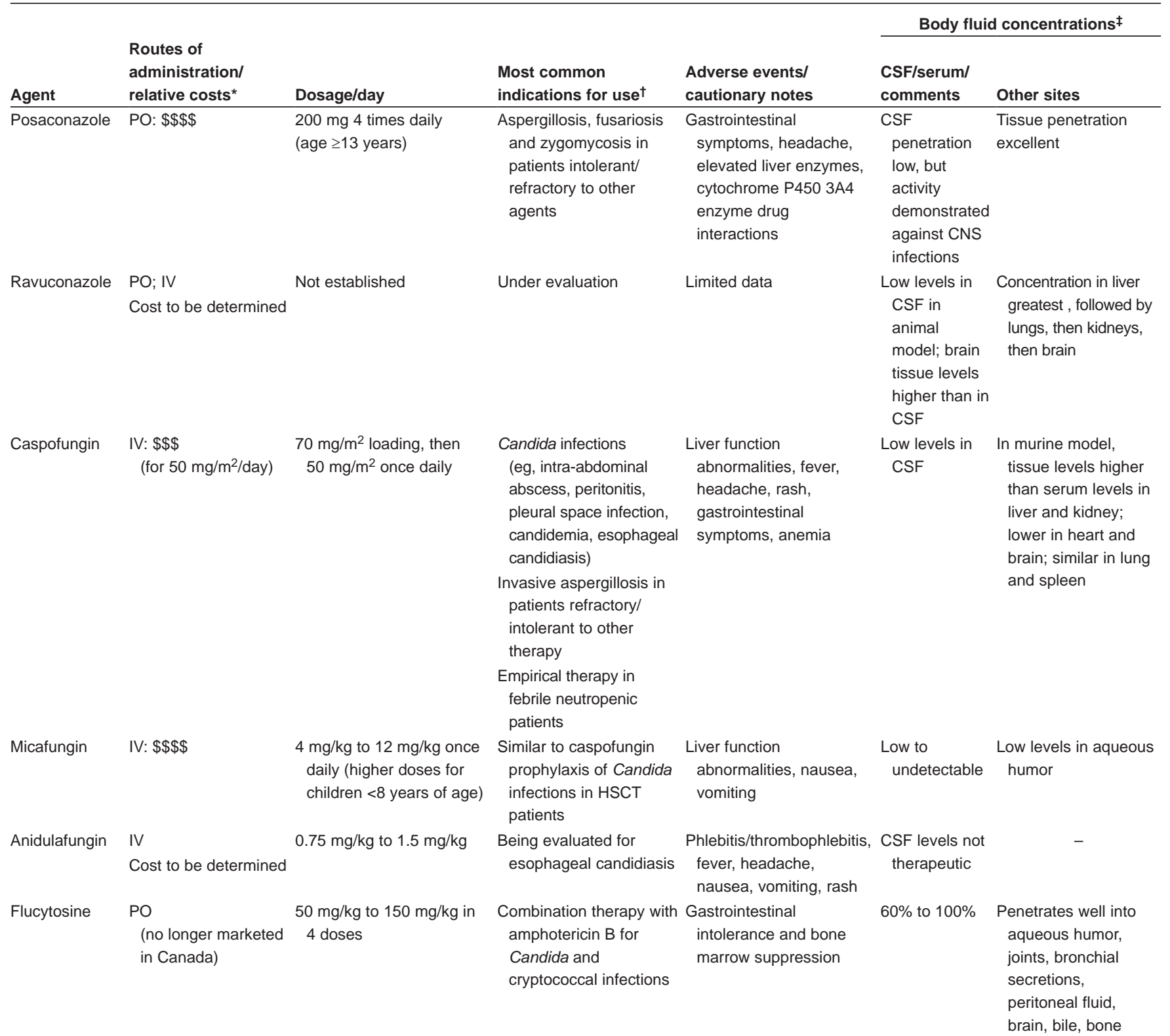

*These costs are for illustrative purposes to show relative costs and are based on the treatment of a $20 \mathrm{~kg}$ child for five days at The Hospital for Sick Children, Toronto, Ontario (modified from the 2009/2010 Drug Handbook and Formulary, The Hospital for Sick Children). Costs may vary across provinces. Doses may also vary depending on the nature of the illness. The costs reflect drug costs only; ${ }^{\dagger}$ This is not meant to be an all inclusive list; it includes licensed indications plus key scenarios in which the drugs have been identified as acceptable therapy; ${ }^{\ddagger}$ Data are lacking regarding tissue levels for several antifungal agents. Available data are summarized in different formats based on how they were generated; ${ }^{\S} \mathrm{A}$ prospective surveillance study suggested little or no benefit when a titrated dosing regimen is used (39). $\$<\$ 200 ; \$ \$ 200$ to $\$ 500, \$ \$ \$ 500$ to $\$ 750 ; \$ \$ \$ \$ 750$ to $\$ 1200$; bid Twice a day; CNS Central nervous system; CSF Cerebrospinal fluid; HSCT Hematopoietic stem cell transplant; IV Intravenous; PO Oral

bioavailable. Concentrations in urine are several fold greater than in blood (10- to 20-fold greater) $(11,12)$. Rare, but serious, hepatotoxicity may be associated with fluconazole. Drug interactions are possible because fluconazole is an inducer of cytochrome P450 isoenzymes.

Clinical use in paediatrics: Fluconazole, the azole that is most widely used in paediatrics, is often used in the treatment of Candida and cryptococcal infections. It is more active against Candida albicans compared with other candidial strains (eg, Candida parapsilosis, Candida glabrata, Candida krusei and
Candida tropicalis). It has no activity against Aspergillus species or other moulds. As a prophylactic agent, fluconazole is used in allogeneic hematopoietic stem cell transplant recipients (13). Data are emerging on its role as a prophylactic agent in neonates at high risk of invasive candidiasis $(14,15)$.

Itraconazole: Itraconazole is available for oral and parenteral administration (16). Pharmacokinetic studies (17) of itraconazole oral solution have demonstrated that children younger than five years of age tend to have lower plasma concentrations than older children or adults. Gastrointestinal 
TABLE 2

Spectrum of activity of more commonly used systemic antifungal agents

\begin{tabular}{|c|c|c|c|c|c|}
\hline \multirow[b]{2}{*}{ Selected fungal species } & \multicolumn{5}{|c|}{ Antifungal agents* } \\
\hline & Amphotericin B products & Fluconazole & Voriconazole & Posaconazole & Echinocandins \\
\hline Aspergillus fumigatus & ++ & - & +++ & +++ & ++ \\
\hline Aspergillus terreus & - & - & +++ & +++ & ++ \\
\hline Candida albicans & +++ & +++ & +++ & +++ & +++ \\
\hline Candida glabrata & ++ & $+1-$ & + & + & +++ \\
\hline Candida lusitaniae & $+1-$ & + & ++ & ++ & ++ \\
\hline Candida krusei & ++ & - & ++ & ++ & +++ \\
\hline Candida parapsilosis & +++ & +++ & +++ & +++ & ++ \\
\hline Candida guilliermondii & ++ & +++ & +++ & +++ & ++ \\
\hline Cryptococcus neoformans & +++ & +++ & +++ & +++ & - \\
\hline Fusarium species & 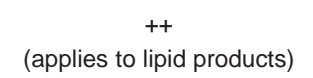 & - & ++ & ++ & - \\
\hline Dematiaceous moulds $^{\dagger}$ & + & $+1-$ & +++ & +++ & + \\
\hline Dimorphic fungi ${ }^{\ddagger}$ & +++ & $\begin{array}{c}+ \\
+++ \text { Coccidioides } \\
+ \text { +- Sporothrix }\end{array}$ & $\begin{array}{c}++ \\
- \text { Sporothrix }\end{array}$ & $\begin{array}{c}++ \\
+ \text { Sporothrix }\end{array}$ & - \\
\hline
\end{tabular}

The above is based on in vitro activity, which does not always predict outcomes in clinical practice. *Flucytosine: Use only in combination therapy for Candida, Cryptococcus neoformans and selected dematiaceous moulds; ${ }^{\dagger}$ Dematiaceous moulds: Alternaria, Bipolaris, Curvularia, Exophiala; ${ }^{\ddagger}$ Dimorphic fungi: Blastomycetes dermatitidis, Coccidioides immitis/posadasii, Histoplasma capsulatum, Sporothrix schenckii. Itraconazole is a first-line therapy for dimorphic fungi. Adapted from reference 40

intolerance, related to the osmotic properties of the cyclodextrin carrier, appears to be the dose-limiting toxicity of the itraconazole oral solution (18). Common adverse events include abdominal pain, vomiting, diarrhea and elevated liver enzymes. Given that itraconazole inhibits the cytochrome P450 3A4 enzyme, drug interactions are common.

Clinical use in paediatrics: Itraconazole may be advantageous for prophylaxis in situations in which prevention of Candida and Aspergillus infections are desirable (eg, hematopoietic stem cell transplant recipients) (19). It is often used for prophylaxis in lung transplant recipients who are colonized by Aspergillus (20). The drug is also used selectively in severe Aspergillus infections or as step-down therapy.

Voriconazole: Voriconazole is available as an oral or parenteral formulation. The intravenous formulation should be avoided in patients experiencing moderate or severe renal failure because of the potential toxic effects of the accumulation of the solvent vehicle. Voriconazole plasma levels are very variable among individuals. Children have a higher capacity for elimination of voriconazole compared with adults (21). The paediatric dose that is equivalent in drug exposure to the usual adult maintenance dose of $4 \mathrm{mg} / \mathrm{kg}$, twice a day (bid), remains to be determined. Current recommendations suggest that the paediatric dose of voriconazole should be $8 \mathrm{mg} / \mathrm{kg}$ bid for one day, then $7 \mathrm{mg} / \mathrm{kg}$ bid for the treatment of invasive aspergillosis (22).

Adverse events include skin rash, visual abnormalities, (photophobia and blurred vision) photosensitivity reactions and elevated hepatic transaminase or serum bilirubin levels (23). All are generally reversible.
Clinical use in paediatrics: The main role for voriconazole is in the treatment of invasive aspergillosis, where it has emerged as the preferred treatment of invasive pulmonary aspergillosis in older children and adults $(24,25)$. It may also be used to treat systemic Candida infections, although in clinical practice, fluconazole would be considered first.

Posaconazole: This drug is currently available as an oral agent. It is a second-generation triazole that is structurally similar to itraconazole $(6,26)$. It is a broad-spectrum agent with activity against Candida species, Aspergillus species and zygomycetes, among other fungal organisms (Table 2).

Clinical use in paediatrics: Paediatric experience is limited (26). Currently, in clinical practice, this agent is being used as salvage therapy in situations in which first-line antifungal agents have failed or are contraindicated due to toxicity. Infections that have been treated include invasive aspergillosis and zygomycetes infection. It is also used for prophylaxis among allogeneic hematopoietic stem cell transplant recipients and selected high-risk cancer patients.

Ravuconazole: Ravuconazole is available as oral and intravenous formulations. Structurally similar to fluconazole and voriconazole, it has a half-life of approximately $100 \mathrm{~h}(6,27)$, which would make it ideal for step-down therapy and treatment in ambulatory care settings (28). It has activity against Candida species, Aspergillus species, Cryptococcus neoformans, Histoplasma capsulatum and Coccidioides immitis (Table 2). The safety profile appears to be similar to fluconazole.

Clinical use in paediatrics: Paediatric experience is lacking. Isavuconazole: Isavuconazole is a new triazole with oral and intravenous formulations. It is currently undergoing 
phase III clinical trials in adults (29). It is a broad-spectrum agent with in vitro activity against most yeasts and moulds including fluconazole-resistant Candida strains, Aspergillus species and to a limited degree, zygomycetes (30).

Clinical use in paediatrics: Paediatric experience is lacking.

\section{Mechanism of action}

\section{THE ECHINOCANDINS}

These agents are glucan synthesis inhibitors that specifically inhibit beta (1-3)-D-glucan synthesis, thereby compromising the integrity of the fungal cell wall. Beta (1-3)-D-glucan synthesis does not occur in human cells.

\section{Preparations, dosing and toxicity profiles}

All are available only as parenteral formulations. To date, serious toxicities described with these drugs are uncommon.

Caspofungin: Dosing based on body surface area appears to be a more appropriate approach to dosing than a body weight approach; with $50 \mathrm{mg} / \mathrm{m}^{2} /$ day, the area under the curve following multiple doses is similar to adults receiving $50 \mathrm{mg} /$ day. The area under the curve and trough plasma concentrations were consistent among children and adolescents two to 17 years of age. However, younger children tend to have increased clearance (and thus a shorter half-life) of caspofungin compared with older children or adults (27).

Clinical use in paediatrics: Caspofungin is the echinocandin that has been most widely used in clinical practice (31-33). The drug is effective in treating invasive candidiasis and aspergillosis. It has emerged as an effective agent in the treatment of invasive pulmonary aspergillosis (25). In some centres, it is widely used as empirical treatment in febrile neutropenic patients with impaired renal function (33).

Micafungin: Linear pharmacokinetics occur over the dose range of $0.5 \mathrm{mg} / \mathrm{kg} /$ day to $4.0 \mathrm{mg} / \mathrm{kg} / \mathrm{day}$ (34). Among children two to eight years of age, clearance is greater than that of older patients. Among premature infants weighing more than $1000 \mathrm{~g}$, single doses of micafungin, ranging up to $3.0 \mathrm{mg} / \mathrm{kg}$, were well tolerated with the elimination of half-life $(8 \mathrm{~h})$ and total plasma clearance in these infants being dissimilar to that reported for older children and adults. The half-life among premature neonates weighing $500 \mathrm{~g}$ to $1000 \mathrm{~g}$ was $5.5 \mathrm{~h}$ (35).

\section{REFERENCES}

1. Antachopoulos C, Walsh TJ. New agents for invasive mycoses in children. Curr Opin Pediatr 2005;17:78-87.

2. Walsh TJ, Whitcomb P, Piscitelli S, et al. Safety, tolerance, and pharmacokinetics of amphotericin B lipid complex in children with hepatosplenic candidiasis. Antimicrob Agents Chemother 1997;41:1944-8.

3. Walsh TJ, Seibel NL, Arndt C, et al. Amphotericin B lipid complex in pediatric patients with invasive fungal infections. Pediatr Infect Dis J 1999;18:702-8.

4. Wiley JM, Seibel NL, Walsh TJ. Efficacy and safety of amphotericin B lipid complex in 548 children and adolescents with invasive fungal infections. Pediatr Infect Dis J 2005;24:167-74.

5. Herbrecht R, Auvrignon A, Andres E, et al. Efficacy of amphotericin B lipid complex in the treatment of invasive fungal infections in immunosuppressed paediatric patients. Eur J Clin Microbiol Infect Dis 2001;20:77-82.
Clinical use in paediatrics: Micafungin has been evaluated in several paediatric studies. The indications for the use of caspofungin apply (36). It is an effective agent for fungal prophylaxis in hematopoietic stem cell transplant recipients (37).

Anidulafungin: Limited paediatric data are available for this intravenous agent. It has the longest half-life of all echinocandins (approximately $18 \mathrm{~h}$ ) and is administered once daily. Tissue concentrations are highest in the lung and liver, followed by the spleen and kidneys (38).

Clinical use in paediatrics: Paediatric experience is limited.

\section{ANTIMETABOLITES - FLUCYTOSINE}

\section{Preparations, dosing and toxicity profiles}

Flucytosine is available as an oral agent. Gastrointestinal intolerance and bone marrow suppression are common. Rash, hepatotoxicity, headache, confusion, hallucinations, sedation and euphoria may occur. When combined with amphotericin B, the renal impairment caused by amphotericin B may increase the flucytosine levels in the body and, thus, potentiate its toxicity.

Clinical use in paediatrics: There is a large body of clinical experience with flucytosine in paediatrics, although clinical trial data are limited $(22,27)$. It is invariably used in combination with amphotericin B in the treatment of Candida or cryptococcal infections, notably involving the central nervous system.

\section{COMBINATIONS OF ANTIFUNGAL AGENTS}

There is no convincing evidence that combination antifungal therapy offers advantages over monotherapy with the exception of therapy for cryptococcal meningitis. However, many experts advise combination therapy for some conditions including central nervous system fungal infections; disease with incomplete response to initial therapy, notably where optimal dosing is compromised by toxicity; empirical therapy of severe disease presumed to be due to organisms that are known to have distinct fungal susceptibility profiles (ie, a different drug is needed for each likely pathogen); and initial therapy of selected cases of invasive pulmonary aspergillosis, particularly for diseases in close proximity to major mediastinal blood vessels.
6. Groll AH, Gea-Banacloche JC, Glasmacher A, et al. Clinical pharmacology of antifungal compounds. Infect Dis Clin North Am 2003;17:159-91.

7. Scarcella A, Pasquariello MB, Giugliano B, Vendemmia M, de Lucia A. Liposomal amphotericin B treatment for neonatal fungal infections. Pediatr Infect Dis J 1998;17:146-8

8. Koren G, Lau A, Kenyon CF, Kroppert D, Klein J. Clinical course and pharmacokinetics following a massive overdose of amphotericin B in a neonate. J Toxicol Clin Toxicol 1990;28:371-8.

9. American Academy of Pediatrics. Antifungal drugs for systemic fungal infections. In: Pickering LK, Baker CJ, Long SS,

McMillan JA, eds. Red Book 2006 Report of the Committee on Infectious Diseases, 27th edn. Elk Grove Village, IL: American Academy of Pediatrics, 2006:775.

10. Bowden R, Chandrasekar P, White MH, et al. A double-blind, randomized, controlled trial of amphotericin $\mathrm{B}$ colloidal dispersion 
versus amphotericin B for treatment of invasive aspergillosis in immunocompromised patients. Clin Infect Dis 2002;35:359-66.

11. Brammer KW, Coates PE. Pharmacokinetics of fluconazole in pediatric patients. E J Clin Microbiol Infect Dis 1994;13:325-9.

12. Debruyne D. Clinical pharmacokinetics of fluconazole in superficial and systemic mycoses. Clin Pharmacokinet 1997;33:52-77.

13. Marr KA, Seidel K, Slavin MA, et al. Prolonged fluconazole prophylaxis is associated with persistent protection against candidiasis-related death in allogeneic marrow transplant patients: Long-term follow-up of a randomized, placebo-controlled trial. Blood 2000;96:2055-61.

14. McGuire W, Clerihew L, Austin N. Prophylactic intravenous antifungal agents to prevent mortality and morbidity in very low birth weight infants. Cochrane Database Syst Rev 2004;1:CD003850.

15. Manzoni P, Stolfi L, Pugni L, et al. A multicenter, randomized trial of prophylactic fluconazole in preterm neonates. N Eng J Med 2007;356:2483-95.

16. Prentice AG, Glasmacher A. Making sense of itraconazole pharmacokinetics. J Antimicrob Chemother 2005;56:i17-i22.

17. de Repentigny L, Ratelle J, Leclerc JM, et al. Repeated-dose pharmacokinetics of an oral solution of itraconazole in infants and children. Antimicrob Agents Chemother 1998;42:404-8.

18. Groll AH, Wood L, Roden M, et al. Safety, pharmacokinetics, and pharmacodynamics of cyclodextrin itraconazole in pediatric patients with oropharyngeal candidiasis. Antimicrob Agents Chemother 2002;46:2554-63.

19. Foot AB, Veys PA, Gibson BE. Itraconazole oral solution as antifungal prophylaxis in children undergoing stem cell transplantation or intensive chemotherapy for haematological disorders. Bone Marrow Transplant 1999;24:1089-93.

20. Minari A, Husni R, Avery RK, et al. The incidence of invasive aspergillosis among solid organ transplant recipients and implications for prophylaxis in lung transplants. Transpl Infect Dis 2002;4:195-200.

21. Jeu L, Piacenti FJ, Lyakhovetskiy AG, Fung HB. Voriconazole. Clin Ther 2003;25:1321-81.

22. American Academy of Pediatrics. Recommended doses of parenteral and oral antifungal drugs. In: Pickering LK, Baker CJ, Long SS, McMillan JA, eds. Red Book 2006 Report of the Committee on Infectious Diseases, 27th edn. Elk Grove Village, IL: American Academy of Pediatrics, 2006:779.

23. Walsh TJ, Lutsar I, Driscoll T, et al. Voriconazole in the treatment of aspergillosis, scedosporiosis and other invasive fungal infections in children. Pediatr Infect Dis J 2002;21:240-8.

24. Herbrecht R, Denning DW, Patterson TF, et al. Voriconazole versus amphotericin B for primary therapy of invasive aspergillosis. N Eng J Med 2004;347:408-15.
25. Walsh TJ, Anaissie EJ, Denning DW, et al. Treatment of aspergillosis: Clinical practice guidelines of the Infectious Diseases Society of America. Clin Infect Dis 2008;46:327-60.

26. Nagappan V, Deresinski S. Reviews of anti-infective agents: Posaconazole: A broad-spectrum triazole antifungal agent. Clin Infect Dis 2007;45:1610-7.

27. Steinbach WJ. Antifungal agents in children. Pediatr Clin North Am 2005;52:895-915.

28. Pannaraj PS, Walsh TJ, Baker CJ. Advances in antifungal therapy. Pediatr Infect Dis J 2005;24:921-2.

29. Isavuconazole for primary treatment of invasive apergillosis: A phase III, double blind, randomized study to evaluate safety and efficacy of isavuconazole versus voriconazole for primary treatment of invasive fungal disease caused by Apergillus species and other filamentous fungi. <http://clinicaltrials.gov/ct2/show/ NCT00412893> (Accessed on September 14, 2010).

30. Guinea J, Pelaez T, Recio S, Torres-Narbona M, Bouza E. In-vitro antifungal activities of isavuconazole (BAL4815), voriconazole and fluconazole against 1007 isolates of Zygomycete, Candida, Aspergillus, Fusarium and Scedosporium species. Antimicrob Agents Chemother 2008;52:1396-400.

31. Deresinski SC, Stevens DA. Caspofungin. Clin Infect Dis 2003;36:1445-57.

32. Mora-Duarte J, Betts R, Rotstein C, et al. Comparison of caspofungin and amphotericin $\mathrm{B}$ for invasive candidiasis. N Eng J Med 2002;347:2020-9.

33. Walsh TJ, Teppler H, Donowitz GR, et al. Caspofungin versus liposomal amphotericin B for empirical antifungal therapy in patients with persistent fever and neutropenia. N Eng J Med 2004;351:1391-402.

34. Seibel NL, Schwartz C, Arrieta A, et al. Safety, tolerability, and pharmacokinetics of Micafungin (FK463) in febrile neutropenic pediatric patients. Antimicrob Agents Chemother 2005;49:3317-24.

35. Heresi GP, Gerstmann DR, Reed MD, et al. The pharmacokinetics and safety of micafungin, a novel echinocandin, in premature infants. Pediatr Infect Dis J 2006;25:1110-5.

36. Chandrasekar PH, Sobel JD. Micafungin: A new echinocandin. Clin Infect Dis 2006;42:1171-8.

37. van Burik JA, Ratanatharathorn V, Stepan DE, et al. Micafungin versus fluconazole for prophylaxis against invasive fungal infections during neutropenia in patients undergoing hematopoietic stem cell transplantation. Clin Infect Dis 2004;39:1407-16.

38. Vazquez JA, Sobel JD. Anidulafungin: A novel echinocandin. Clin Infect Dis 2006;43:215-22.

39. Grasela TH Jr, Goodwin SD, Walawander MK, Cramer RL, Fuhs DW, Moriarty VP. Prospective surveillance of intravenous amphotericin B use patterns. Pharmacotherapy 1990;10:342-8.

40. David N, Gilbert MD. Sanford Guide to Antimicrobial Therapy 2009, 39th edn. Sperryville: Antimicrobial Therapy, 2009.

\section{INFECTIOUS DISEASES AND IMMUNIZATION COMMITTEE}

Members: Drs Robert Bortolussi, IWK Health Centre, Halifax, Nova Scotia (Chair); Jane Finlay, Richmond, British Columbia; Jane C McDonald, The Montreal Children's Hospital, Montreal, Quebec; Heather Onyett, Queen's University, Kingston, Ontario; Joan L Robinson, Edmonton, Alberta; Élisabeth Rousseau-Harsany, Sainte-Justine UHC, Montreal, Quebec (Board Representative) Liaisons: Drs Upton D Allen, The Hospital for Sick Children, Toronto, Ontario (Canadian Pediatric AIDS Research Group); Charles PS Hui, Children's Hospital of Eastern Ontario, Ottawa, Ontario (CPS Liaison to Health Canada, Committee to Advise on Tropical Medicine and Travel); Nicole Le Saux, Children's Hospital of Eastern Ontario, Ottawa, Ontario (Immunization Program, ACTive); Larry Pickering, Elk Grove, Illinois, USA (American Academy of Pediatrics); Marina I Salvadori, Children's Hospital of Western Ontario, London, Ontario (CPS Liaison to Health Canada, National Advisory Committee on Immunization)

Consultants: Drs James Kellner, Calgary, Alberta; Noni E MacDonald, IWK Health Centre, Halifax, Nova Scotia; Dorothy L Moore, The Montreal Children's Hospital, Montreal, Quebec

Principal author: Dr Upton D Allen, Toronto, Ontario

The recommendations in this statement do not indicate an exclusive course of treatment or procedure to be followed. Variations, taking into account individual circumstances, may be appropriate. All Canadian Paediatric Society position statements and practice points are reviewed, revised or retired as needed on a regular basis. Please consult the "Position Statements" section of the CPS website (www.cps.ca/ english/publications/statementsindex.htm) for the most current version. This article also appears in the November 2010 issue of Paediatrics E) Child Health. 


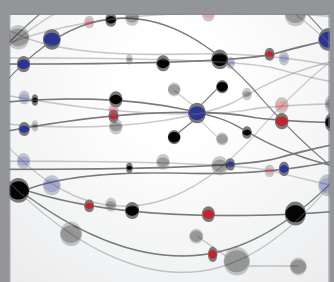

The Scientific World Journal
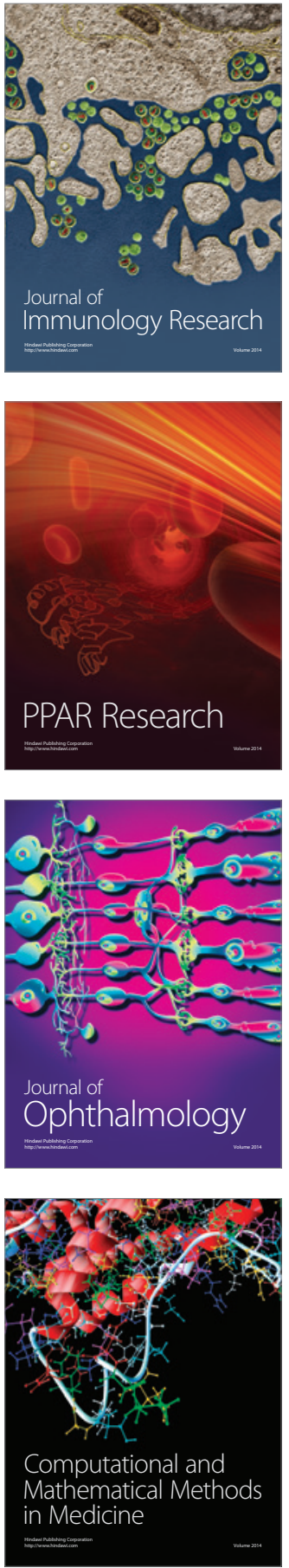

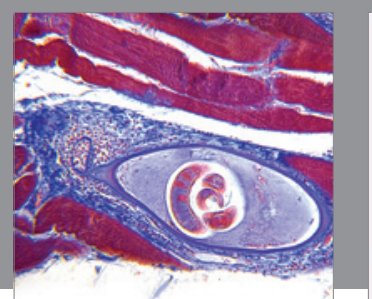

Gastroenterology Research and Practice

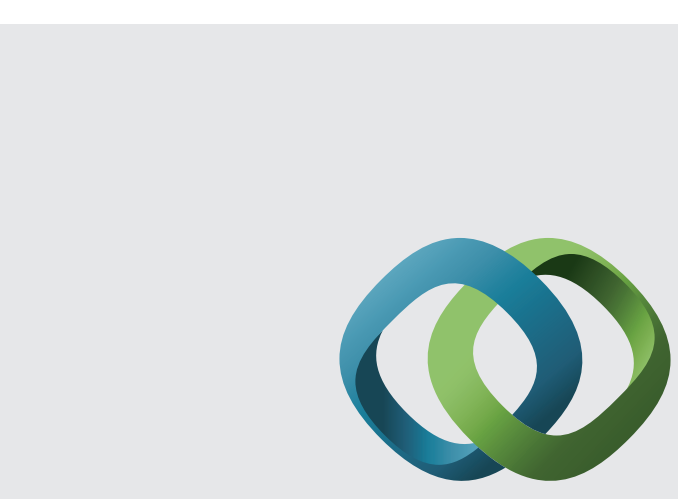

\section{Hindawi}

Submit your manuscripts at

http://www.hindawi.com
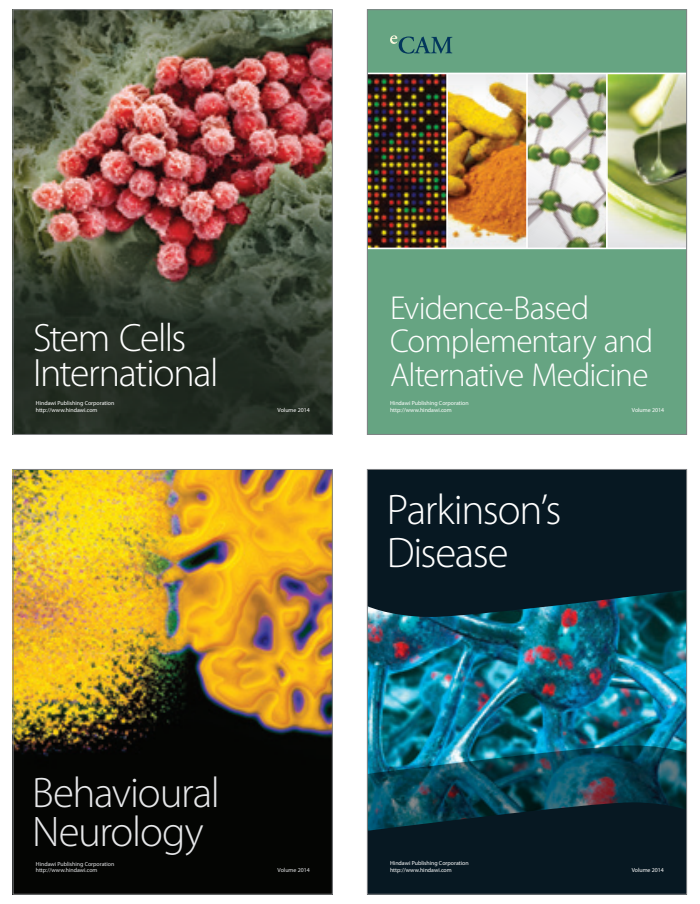
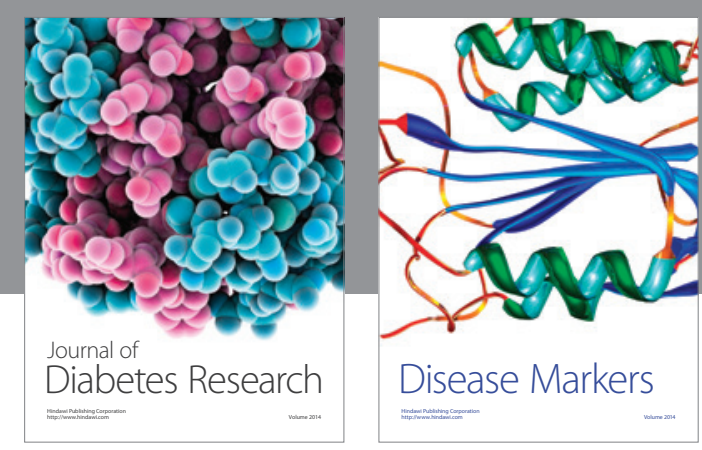

Disease Markers
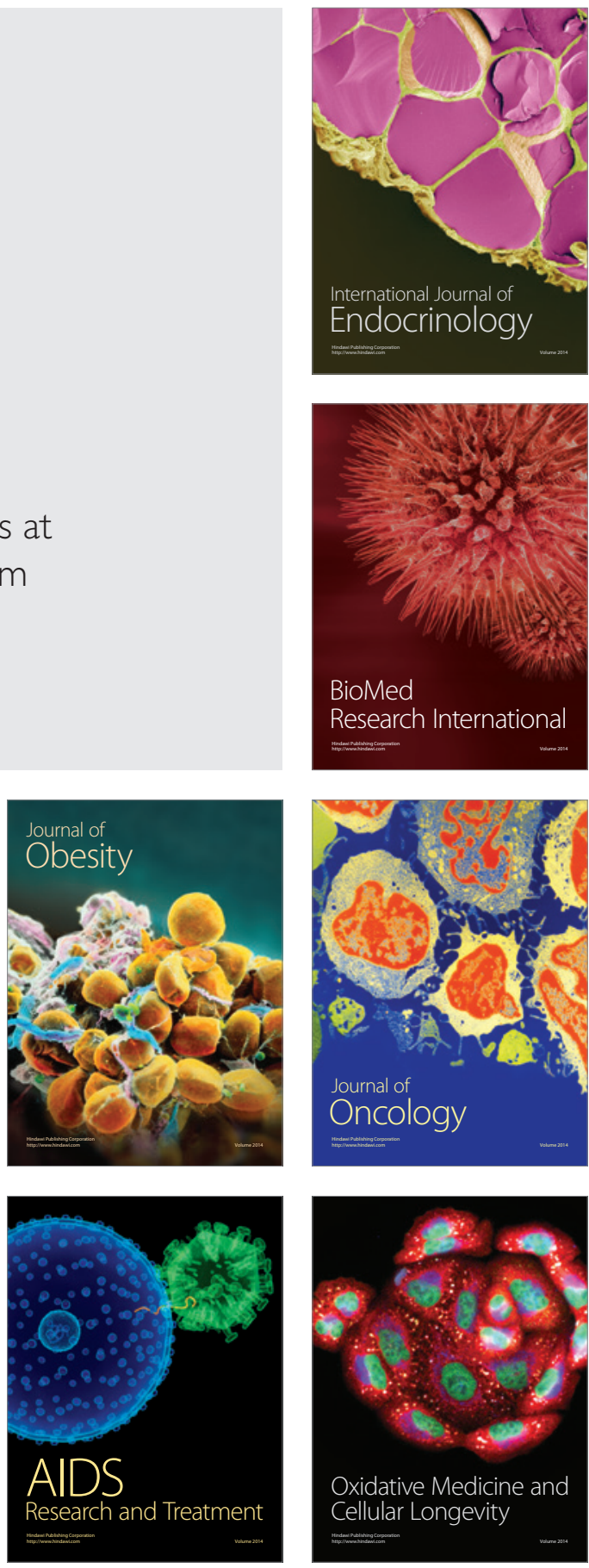